\title{
FORUM NON CONVENIENS, INJUNCTIONS AGAINST SUIT AND FULE FAITH AND CREDIT
}

The traditional transitory cause of action ${ }^{1}$ is no longer characterized by the unqualified prerogative of the plaintiff to try his claim in any jurisdiction in which process may be served on the defendant. Inroads on the power of the plaintiff to determine the forum for trial have developed in this century in the form of two devices whereby the defendant may overcome the plaintiff's choice of forum and relocate the place of trial in a state more conducive to a full hearing of the evidence and more convenient to the litigants and witnesses. ${ }^{2}$ The remedy initially available to the defendant lay in a suit in a sister state to enjoin his adversary from proceeding in the forum alleged to be objectionable. ${ }^{3}$ Upon the issuance of an injunction, the action would be relocated in another jurisdiction: ${ }^{4}$ (a) if the threat of contempt proceeding or other enforcement techniques induced the opposing party to consent to a dismissal in the forum deemed objectionable, 5 and (b) if the plaintiff chose to

1 To say that a cause of action is transitory and not local is only to say that it need not be litigated in a particular forum. The local action, in contrast, must be tried in the jurisdiction in which the claim is thought to have arisen. Attempts have been made, however, to relate the jurisdictional distinction with the substantive content of actions in each category. In this sense, a transitory cause of action is one that might have arisen anywhere, while a local action is one that could arise only in the jurisdiction in which it must be tried. The reasoning as to jurisdictional limitations seems to be this: an action which arises locally should be sued upon locally; an action that could have arisen anywhere should be triable anywhere. And thus, by the "nature" of a transitory action, the plaintiff has been thought to have a right to determine the place of trial. See note 34, infra. See generally, Currie, The Constitution and the Transitory Cause of Action, 73 HARV. L. REv. 36 (1959); and particularly his whimsical insight into the perplexities of defining the terms, id. at $66, \mathrm{n} .114$.

2 Another limitation on the plaintiff's option to determine the forum is the constitutional restraint against imposing undue burdens on interstate commerce. See, e.g., Denver \& R.G.W. R.R. v. Terte, 284 U.S. 284 (1932); Michigan Cent. R.R. v. Mix, 278 U.S. 492 (1929); Davis v. Farmers' Co-op Co., 262 U.S. 312 (1923).

3 Injunctions against suits in sister states were used originally to prevent circumvention by state residents of insolvency and debtors' exemption of other residents. E.g., Allen v. Buchanan, 97. Ala. 399, 11 So. 777 (1892); Wilson v. Joseph, 107 Ind. 490, 8 N.E. 616 (1886); Hawkins v. Ireland, 64 Minn. 339, 67 N.W. 73 (1896).

4 In contrast to the informal two-step process of transference between separate states, transference in the Federal courts may be effected by motion in the forum initially selected. The statutory basis for the remedy, 62 Stat. 937 (1948), 28 U.S.C. $\S 1404$ (a) (1958), provides: "For the convenience of parties and witnesses, in the interest of justice, a district court may transfer any civil action to any other district or division where it might have been brought."

5 One technique is to enjoin witnesses from participation in the action so long as it is located in the forum deemed inappropriate; see Peterson v. Chicago B. \& O. R.R., 187 Minn. 228, 244 N.W. 823 (1932). Another device, if the court has a particular relation to the res of the controversy, is to threaten nonaccess to the forum and thus to satisfaction of a foreign judgment as long as the enjoined party acts in violation of injunction. See Wehrhane v. Peyton, 134 Conn. 486, 58 A.2d 698 (1948). If the defendant appears before the court as the trustee of a res located in the jurisdiction, the court may threaten to remove him from that capacity if he should violate the injunction. Doerr v. Warner, 247 Minn. 98, 76 N.W.2d 505 (1956). 
initiate his claim in a forum permitted by the terms of the injunction. ${ }^{6}$ The second step, initiation of the suit in the more suitable forum, causes duplication of the preliminary stages of the litigation; for a second time, the complaint must be filed and process must be served on the defendant. Owing in part to this duplication, transfers are thought advisable only when the increase in convenience is substantial. 7

In theory, the number of forums to which an action may be transferred by use of the injunction includes all those that might be more suitable than the forum initially chosen by the plaintiff. Traditionally, actions have been transferred only to the enjoining forum, and thus, only to a jurisdiction in which process may be served on the plaintiff-the party to be enjoined. An additional convention tends further to narrow the range of acceptable forums. Generally, the state selected for an injunction suit is the state in which the claim has arisen. As a result, in tort litigation, a transfer by use of the injunction has served to guarantee application of the lex loci in the adjudication of the claim.

Adopted more recently by several American jurisdictions 8 as a second method by which to remedy an inappropriate choice of forum, the doctrine of forum non conveniens enables the defendant to initiate relocation of the action in a more suitable jurisdiction by moving for dismissal in a forum selected by the plaintiff. 9 As in injunctive relief, the transfer between jurisdictions is completed when the plaintiff commences his action in a forum more suitable for trial.10 The forum that grants a dismissal on the grounds of

6 The terms of the injunction may permit resumption of suit in a forum other than the one issuing the injunction. See Southem Ry. v. Painter, 314 U.S. 155 (1941).

7 For other considerations influencing the level of inconvenience requisite for injunctive relief, see text accompanying notes 32-34, infra. See also note 10, infra. In transfers within the federal system, the action need not be recommenced in the transferee forum. 62 Stat. 937 (1948), 28 U.S.C. 1404 (a); see note 4, supra. The level of inconvenience necessary for a dismissal reflects the fact that the action is not dismissed and that recommencement is not required. Norwood v. Kirkpatrick, 349 U.S. 29 (1955).

8 Of the populous states, Missouri, Texas, and Ohio have not yet adopted the doctrine of forum non conveniens. See generally the appendix to Lansvek v. Studebaker-Packard Corp., 54 Wash. 2d 774, 338 P.2d 747 (1959). For an analysis of the reasons why states do not accept the doctrine, see note 45 , infra.

9 The history of the doctrine of forum non conveniens and its absorption into American practice has been well documented in the periodical literature. Barrett, The Doctrine of Forum Non Conveniens, 35 CALIf. L. REv. 380 (1947); Blair, The Doctrine of Forum Non Conveniens in Anglo-American Law, 29 CoLUM. L. Rev. 1 (1929); Braucher, The Inconvenient Federal Forum, 60 HARv. L. Rev. 908 (1947); Dainow, The Inappropriate Forum, 29 ILL. L. REv. 867 (1935); Foster, Place of Trial-Interstate Application of Intrastate Methods of Adjustment, 44 HaRv. L. REv. 41 (1930).

${ }^{10} \mathrm{As}$ in the use of the injunction, the increment of inconvenience must be substantial. "[U]nless the balance is strongly in favor of the defendant, the plaintiff's choice of forum should rarely be disturbed." Gulf Oil Corp. v. Gilbert, 330 U.S. 501, 508 (1947). $C f$. text at note 42 , infra. See note 7, supra. 
forum non conveniens may cause the action to be transferred to a particular jurisdiction by conditioning the dismissal on a stipulation by the defendant to submit to suit in the forum deemed by the dismissing court to be most desirable. ${ }^{11}$

Thus, under both remedies, relocation of the place of trial occurs in four stages: (1) the granting of relief; (2) discontinuance of the action in the original forum;12 (3) commencement of suit in the forum preferred by the defendant; (4) retention of jurisdiction by the preferred forum.

In the use of either remedy, a risk of failure occurs at only one step in the process. When a forum non conveniens dismissal is the method selected, the fourth stage is critical, for the forum to which the action is directed need not

11 The condition of the dismissal isually appears as a stipulation by defendant that if the plaintiff commences the action in the preferred forum, defendant will enter an appearance and will not plead the statute of limitations. Vargas v. A. H. Bull Steamship Co., 44 N.J. Super. 536, 131 A.2d 39 (1957), aff'd 25 N.J. 293, 135 A.2d 857 (1957) (payment of plaintiff's attorney fees in the dismissing forum interpreted as a condition for transference); Winter v. General Tire \& Rubber Co., 13 App. Div. 2d 740, 212 N.Y.S.2d 285 (1961); Ginsburg v. Hearst Publishing Co., 5 App. Div. 2d 200, 170 N.Y.S.2d 691 (1958); Rodriguez v. A. H. Bull Steamship Co., 286. App. Div. 207, 143 N.Y.S.2d 618 (1955); Ivy v. Stoddard, 147 N.Y.S.2d 469 (Sup. Ct. 1955). Declining jurisdiction in Gore v. United States Steel Corp., 15 N.J. 301, 104 A.2d 670 (1954), the court warned the defendant that a failure to comply with the conditions of the dismissal would remove any bars to a subsequent suit in New Jersey.

When local limitations prevent or threaten to prevent continuation of the action in a more suitable jurisdiction and the forum would not permit defendant to waive his defense of the statute of limitations, motions to dismiss on the ground of forum non conveniens have been denied. Peterie v. Thompson, 10 III. App. 2d 100, 134 N.E.2d 534 (1956); Taylor v. Interstate Motor Freight Sys., 309 N.Y. 633, 152 N.E.2d 878 (1958); Randle v. Inecto, 131 Misc. 261, 226 N.Y. Supp. 686 (Sup. Ct. 1928). But cf. Price v. Atchison, T. \& S.F. Ry., 42 Cal.2d 577, 268 P.2d 457 (1954).

Dismissals may be granted in the absence of a special stipulation by the defendant, e.g. Elliot v. Johnson, 365 Mo. 881, 292 S.W.2d 589 (1956); Gainer v. Donner, 140 Misc. 841, 251 N.Y. Supp. 713 (Sup. Ct. 1931), but not without proof of the availability of a more suitable forum. City Farmers Trust Co. v. National Cuba Hotel Corp., 133 N.Y.S.2d 12 (Sup Ct. 1954); cf. Bagarozy v. Meneghini, 8 Ill. App.2d 285, 131 N.E.2d 792 (1955). Generally, access to alternative forums in the United States will be assumed unless contested by the plaintiff. Elliot v. Johnson, supra; Gainer v. Donner, supra. The concept of the alternative forum was limited in Hill v. Upper Mississippi Towing Corp., 252 Minn. 165, 89 N.W.2d 654 (1958), to the class of jurisdictions in which the plaintiff in initially filing his action could have served process on the defendant. Thus the unamenability of the defendant corporation to service of process precluded a dismissal despite the defendant's willingness to stipulate as to appearance. For an instance of transference to a jurisdiction in which the defendant could not have been served with process, see Vargas v. A. H. Bull Steamship Co., supra. On this issue, practice in the federal system is determined by the language of 28 U.S.C. 1404(a): the action may be transferred only to those jurisdictions "where it might have been brought." This condition has been interpreted in conformity with the limitation on the use of forum non conveniens imposed by Hill v. Upper Mississippi Towing Corp., supra. Hoffman v. Blaski, 363 U.S. 335 (1960).

12 A note on terminology: the "original forum" will consistently refer to the forum chosen by the plaintiff; the "enjoining forum" is the forum issuing the injunction; "plaintiff" and "defendant," even in discussions of the injunction suit, will refer to the parties as they are aligned in the substantive controversy. 
retain jurisdiction if it disagrees with the decision of the original forum. When injunctive relief is sought in a sister state, however, the granting of an injunction expresses that forum's willingness to adjudicate the plaintiff's claim. The critical stage in injunctive relief occurs at the second stage, that of forcing the discontinuance of the proceedings in the forum in which the action was originally brought. Enforcement techniques are limited. The enjoining forum may threaten contempt proceedings against the plaintiff, enjoin witness, or use other methods of intimidation; but it may not directly restrain the original forum from hearing the case. ${ }^{13}$ The forum in which the action is pending need not recognize the enjoining forum's attempted restraint of the plaintiff.14 Indeed, it may issue a counter-injunction to protect its jurisdiction. ${ }^{15}$ Against nonresidents, enforcement by contempt proceedings is complicated by possible difficulties in obtaining personal jurisdiction over the recalcitrant party. As a result of these difficulties, the plaintiff's action may proceed despite the injunction.

If the Supreme Court were to interpret the full faith and credit clause ${ }^{16}$ to impose on the original forum the duty to recognize the injunction and on that

13 Tyler v. Hammersley, 44 Conn. 419 (1877); Askew v. Bassett Furniture Co., 172 Ga. 700,158 S.E. 577 (1931); Touchstone v. Moore, 227 Miss. 415, 86 So.2d 352 (1956). But cf. Lyle v. Collier, 62 S.W.2d 1112 (Tex. Ct. Civ. App. 1933) (bias on the part of the judge was thought to create a defeat in jurisdiction; and thus, the injunction was permitted.)

14 Though a few courts have dismissed actions in voluntary deference to sister-state injunctions, Allen v. Chicago G.W.A.R., 239 Ill. App. 38 (1925); Fisher v. Pacific Mut. Life Ins. Co., 112 Miss. 30, 72 So. 846 (1916), a substantial number of cases manifest total disregard for the enforcement of sister-state injunctions against suit. Frye v. Chicago R.I. \& P. Ry., 157 Minn. 52, 195 N.W. 629 (1923); Union Pac. R.R. v. Rule, 155 Minn. 302, 193 N.W. 161 (1923); State ex rel. Bosscung v. District Court, 140 Minn. 494, 168 N.W. 589 (1918); Kepner v. Cleveland, C. \& St. L. Ry., 322 Mo. 299, 15 S.W.2d 825 (1929).

In an important early case, Gilman v. Ketcham, 84 Wis. 60, 54 N.W. 395 (1893), recognition on the basis of comity was extended to a sister-state injunction.

The issue of the injunction suit, however, was not the degree of trial inconvenience; the question was solely whether the enjoined party had evaded the insolvency policies of his home state. Since the doctrine of forum non conveniens was not applicable, the injunction did not supersede an alternative remedy in the original forum. Thus, the forum, by recognizing the injunction and dismissing the action, did not abdicate its capacity to decide the issue adjudicated in the injunction suit. Compare James v. Grand Trunk R.R., 14 Ill. 2d 356,152 N.E.2d 858 (1958), in which the Illinois court enjoined the enforcement of a Wisconsin injunction against suit in Illinois; an important consideration in the decision was the failure of the defendant to avail himself of the forum non conveniens remedy in Illinois.

For an argument in favor of full faith and credit recognition of injunctions against suit, see Comment, 26 U. CHI. L. Rev. 633 (1959). See also Currie, Full Faith and Credit to Foreign Land Decrees, 21 U. CHI. L. REv. 620 (1954). See generally, Reese, Full Faith and Credit to Foreign Equity Decrees, 42 Iowa L. REv. 183 (1957).

15 Chicago, M. \& St. P. Ry. v. Schendel, 292 Fed. 326 (8th Cir. 1923); James v. Grand Trunk R.R., 14 Ill.2d 356, 152 N.E.2d 858 (1958); Peterson v. Chicago, B. \& O. Ry., 187 Minn. 228, 224 N.W. 823 (1932).

16 U.S. CoNST. art. IV, §1 "Full Faith and Credit shall be given in each State to the public Acts, Records, and judicial Proceedings of every other State...." 
basis to dismiss the action, 17 the risk of failure in the transfer of actions by injunction would be substantially reduced. After an injunction issued, progression through the remaining three stages of the process would be assured. The original forum would be compelled to dismiss; the plaintiff would be required to bring his action, if at all, in the enjoining forum; and the enjoining forum would retain jurisdiction. To determine whether this increase in effectiveness warrants the extension of full faith and credit recognition to injunctions against suit, the precise operation of the two remedies must be examined, both as presently administered and as they would be administered were the proposed change to take place.

Under present practice, variations in the operation of the two remedies may be found in three areas: (1) the basic prerequisites for relief, (2) the role of factors used to determine the relative convenience of the alternative forums, and (3) the influence of interests local to the forum from which relief is sought.

\section{I}

To secure relief under either remedy, basic rules must be satisfied. These rules focus on the residence of the litigants and, in the case of injunctive relief, on the motive of the plaintiff in choosing the allegedly objectionable forum. By imposing residence limitations, the courts have narrowed the extent to which the device of forum non conveniens may be used. Residence of the plaintiff in the state in which the original action is pending almost always precludes a forum non conveniens dismissal; 18 but this same fact will not bar

17 When injunctions against suit have been recognized on a comity basis, the manner of enforcement has been dismissal of the action. Allen v. Chicago, Great W. R.R., 239 Ill. App. 38 (1925); Fisher v. Pacific Mut. Life Ins. Co., 112 Miss. 30, 72 So. 846 (1916). Thus, recognition by an original forum of an injunction against an action pending therein leads to a means of enforcement not available in the forum in which the injunction was issued.

18 De la Bouillerie v. de Viene, 300 N.Y. 60,89 N.E.2d 15 (1949); Gregonis v. P. \& K. Coal \& Iron Co., 235 N.Y. 152, 139 N.E. 223 (1925); Catugno v. Union Pac. R.R.; 12 Misc. 2d 255, 177 N.Y.S.2d 126 (Sup. Ct. 1958); Chapman v. Southern Ry., 230 S.C. 210, 95 S.E.2d 170 (1956) (dictum); but cf. Gore v. United States Steel Corp., 15 N.J. 301, 104 A.2d 670 (1954)(dictum).

Plaintiff's residence in the state at the time he initiates the action though not at the time when the claim accrued has been held sufficient to bar a dismissal. Bullock v. Tamiami Trail Tours, 7 Misc. 2d 108, 162 N.Y.S.2d 69 (Sup. Ct. 1957). But cf. Missouri, K.T.R.R. v. District Court Okl., 294 P.2d 579 (Okla. Sup. Ct. 1956).

The residence, however, of a plaintiff suing on a derivative claim does not preclude dismissal. Koster v. Lumbermans Mutual Casualty Co., 330 U.S. 518 (1947). Similarly, a resident administrator has been held not to be immune to dismissal. Atchison, T. \& S.F. Ry. v. District Court, 298 P.2d 427 (Okla., Sup. Ct. 1956). Massachusetts and New York differ as to the status of a resident assignee. Compare Universal Adjustment Corp. v. Midland Bank, Ltd., 281 Mass. 303, 184 N.E. 152 (1933) with Wagner v. Braunsberg, 5 App. Div. $2 d 561$ 173 N.Y.S.2d 525 (1958). 
the issuance of an injunction by a sister forum. 19 This divergence in policy toward a plaintiff suing in his home forum appears to derive from the inability of the dismissing forum to enforce its determination that the trial should take place in a particular alternative forum. If a plaintiff were unable to sue in his home forum, and if sister-state forums rigidly applied the doctrine of forum non conveniens to dismiss suits brought by nonresidents, a plaintiff might find himself without a forum in which to litigate his claim. 20

Since the category of "residents" includes both natural persons and domestic corporations, generalizations cannot readily be made as to the evidentiary value of a party's residence on the issue of trial convenience. In weighing the effect of the defendant's residence in the state of suit, the two categories of residents should be treated separately. It may be assumed that a natural person generally would not be inconvenienced if he should be sued in the state of his residence. 21 On the other hand, a domestic corporation conducting a nation-wide business might not regard the state of its legal residence as an especially attractive place for trial. Disregarding the distinction between categories of residents, the New York courts refuse categorically to dismiss actions brought against residents, both natural and corporate.22 Other states have expressly rejected the New York rule.23 In Winsor $v$. United Airlines, ${ }^{24}$ despite

19 Grover v. Woodward, 91 N.J. Eq. 250, 109 Atl. 822 (1920) (dictum). Generally, residence of the plaintiff is of significance in injunctive relief only as a factor bearing on the relative convenience of alternative forums. Nion-residence of the plaintiff in the enjoining states does not bar relief. Wehrhane v. Peyton, 134 Conn. 486, 58 A.2d 698 (1948); Receivers of Middlesex Banking Co. v. Realty Inv. Co., 104 Conn. 206, 132 Atl. 390 (1926); Doerr v. Warner. 247 Minn. 98, 76 N.W.2d 505 (1956), cert. denied 352 U.S. 801 (1956). But cf. Greer v. Cook. 88 Ark. 93, 113 S.W. 1009 (1908); Carpenter, Baggott \& Co. v. Hanes, 162 N.C. 46, 77 S.E. 1101 (1913).

20 Distinguishing between residents and nonresidents in regulating the use of forum non conveniens is consistent with the constitutional command (Article IV, $\S 2$ )that "Citizens of each state shall be entitled to all the Privileges and Immunities of citizens in the several states." Douglas v. New York, N.H. \& H.R.R., 279 U.S. 377 (1929). Discrimination against nonresident plaintifis is regarded as an acceptable expression of state interest. "There are manifest reasons for preferring residents in access to often-overcrowded Courts, both in convenience and in the fact that broadly speaking it is they who pay for maintaining the Courts concemed." 279 L.S. at 387.

Frequently; concern for the interests of taxpayers is raised to justify policies of dismissing actions initiated by nonresidents. See, e.g., Price v. Atchison T. \& S.F. Ry., 42 Cal. 2d 577, 268 P.2d 457 (1954); Peterie v. Thomson, 10 Ill. App.2d 100, 134 N.E.2d 534 (1956).

21 See State of Oklahoma ex rel. Oklahoma Tax Commission v. H. D. Lee Co., 174 Kan. 114,254 P.2d 291 (1953).

22 De la Bouillerie v, de Viene, 300 N.Y. 60, 80 N.E.2d 15 (1949); Vigil v. Cayuga Const. Corp., 185 Misc.2d 680, 58 N.Y.S.2d 343 (Sup. Ct. 1945).

23 The courts of New Jersey and Delaware have dismissed actions on behalf of domestic corporations. Winsor v. United Airlines, 154 A.2d 561 (Del. Super. Ct. 1958); Gore v. United States Steel Corp., 15 N.J. 2d 391, 104 A.2d 670 (1954). In both decisions, the courts expressed disapproval of the inflexibility of the New York policy.

24 154 A.2d 561 (Del. Super. Ct. 1958). 
the status of the defendant as a Delaware corporation, the Delaware court dismissed the action in deference to the courts of Colorado. Offsetting whatever convenience might have been incident to the defendant's legal residence in Delaware, trial in Colorado offered numerous concrete advantages. As a result of the relocation of the trial, witnesses were more readily available to testify, proof was more accessible, and the expense of the trial was minimized.25

In Poole v. Mississippi Publishers Corp., 26 a case decided prior to the announcement in Winsor that Delaware courts would under appropriate circumstances dismiss actions brought against domestic corporations, the defendant corporation advisedly selected the alternative remedy: a suit for injunctive relief in the state preferred.for trial.27 On facts substantially similar to those in Winsor, the injunction was issued. 28

In the Poole case, however, an essential element in the defendant's prayer for injunctive relief was the assertion that the "suit in Delaware ... constitute[d] a fraud . . [ [since it was] not ... filed in good faith but purely as a means of compelling the complainant to settle with the defendants ...."29 The Poole case thus illustrates the general rule that proof of the plaintiff's improper motive is a necessary condition for the issuance of an injunction. 30

25 See the detailed listing by the court of the factors favoring Colorado as the most suitable place for trial, 154 A.2d at 564 .

26208 Miss. 364, 44 So.2d 467 (1950)

27 For other instances of injunctions against suits in sister states granted on behalf of nonresidents, see Wehrhane v. Peyton, 134 Conn. 486; 58 A.2d 698 (1948); Danzies v. Metropolitan Life Ins. Co., 277 N.Y. 564, 13 N.E.2d 475 (1938); Northern Pac. Ry. v. Richey \& Gilbert, 132 Wash. 526, 232 Pac. 355 (1925). Two earlier cases holding to the contrary, Folkes v. Central of Georgia Ry., 202 Ala. 376, 80 So. 458 (1918), and American Express Co. v. Fox, 135 Tenn. 489, 187 S.W. 1117 (1916), were criticized in Northern Pac. Ry. v. Richey \& Gilbert, supra.

28 For detailed allegations of the relative convenience of trial in Mississippi, see 208 Miss. at 372-73, 44 So.2d at 469-70:

29208 Miss. at 373, 44 So. $2 d$ at 470 .

30 When injunctive relief is denied, the ground usually offered is the absence of improperly motivated conduct on the part of the plaintiff. E.g., Bavuso v. Angwin, 166 Kan. 469, 201 P.2d 1057 (1949); Bank Savings Life Ins. Co. v. Wood, 122 Kan. 831, 253 Pac. 431 (1927); New Orleans Brewing Co. v. Cahall, 188 La. 749, 178 So. 339 (1937); Southern Pac. Ry. v. Baum, 39 N.M. 22, 38 P.2d 1106 (1934). In Missouri K.T.R.R. v. Ball, 126 Kan. 745, 271 Pac. 313 (1928), the court justified its refusal to grant injunctive relief on the specific ground that: "Nothing was shown about the motive of the [plaintiff] in bringing the action' in Missouri, and no attempt was made to prove that she was actuated by fraud or a purpose to oppress or to gain an inequitable advantage of the railroad company or to harrass or to annoy that company." 126 Kan. at 748, 271 Pac. at 314.

Disregarding the precedents of other jurisdictions, the Indiana courts have issued injunctions against residents suing out-of-state without demanding a demonstration of improper motive. The out-of-state actions were based on claims arising under the Federal Employer's Liability Act, 35 Stat. 65-66 (1939), 45 U.S.C. $\$ \$ 51-59$ (1958). Kern v. Cleveland, C.C. \& St. L. Ry. v. Shelly, 96 Ind. App. 273, 170 N.E. 328 (1930). 
This requirement, which is not part of the doctrine of forum non conveniens, 31 may have arisen from judicial concern about the disruptive effect of injunctions against suit on interstate relations. 32 To minimize the overtones of interference in official functions of the sister forum, enjoining forums have emphasized the principle that the injunction restrains the plaintiff and not the sister-state court and, consequently, have focused upon the plaintiff's motive rather than upon the propriety of the original forum's retaining jurisdiction. ${ }^{33}$

The rule might also have derived in part from the high regard shown by many of the earlier courts for the plaintiff's right to select the forum for trial. By conditioning relief on the plaintiff's wrongful conduct, the courts were able to justify the limitation on his freedom to choose the forum for trial.34

The lack, however, of a direct relationship between plaintiff's motive in selecting the original forum and the desirability of transfer to a more convenient forum has affected the stringency with which the improper motive must be proved. In the Poole case, for example, the defendant was not require to prove facts pertaining exclusively to the plaintiff's subjective intent in selecting the original forum. The inference that plaintiff's motive was to extort a favorable settlement was based primarily on the degree of expense and inconvenience imposed upon the defendant as a result of the plaintiff's choice of forum. ${ }^{35}$ When an enjoining court permits an inference of impropir motive from the effect of the place of trial on the defendant's convenience, the factual conditions for transference by injunction become identical with the criteria for a forum non conveniens dismissal. 36

31 In applying the doctrine of forum non conveniens, courts typically do not advert to the problem of plaintiff's motive. See cases cited notes $12,17,18$, supra. Some decisions, howiever, have referred to the notions of harrassment and vexation. Continental Casualty Co. v. Hartford Acc. \& Indem. Co., 28 Ill. App.2d 177, 171 N.E. $2 d 68$ (1960) (criticizing a motion to dismiss for not including an allegation of harrassment); Starr v. Berry, 25 N.J. 2d 573,138 A.2d 44 (1958) (associating harrassment with hardship and looking to hardship as the criterion for dismissal). See also Gulf Oil Corp. v. Gilbert, 330 U.S. 501,508 (1947).

: See, e.g., Durrant v. Pierson, 12 N.Y. Supp. 145 (Sup. Ct. 1890); Mead v. Merritt, 2 Paige 402 (N.Y. 1831).

氵s See, e.g., Cole v. Cunningham, 133 L.S. 107 (1890); Hyafill v. Buffalo Marine Co., 266 Fed. 533 (W.D.X.Y. 1919); Bankers Life Ins. Co. צ. Loring, 217 lota 534, 250 N.W. 8 (1933).

34 The "right" of the plaintiff to select the jurisdiction for trial was eloquently appraised by Chancellor Pitney in Bigelow v. Old Dominion Copper Co., 74 N.J. Eq. 457, 71 Atl. 153 (1908); "[E]quity" will not interfere with the right of any person to bring an action for the redress of grievances-the right preservative of all rights-except for grave reasons. ..." 74 N.J. Eq. at 473, 71 Atl. at 160. In Baltimore \& O. R.R. v. Halchak, 71 F. Supp. 224 (W.D. Pa. 1947), the court, denying the prayer for injunctive relief, referred to the "undeniable right of the resident of one state to go into the courts of another state and secure such relief as there may be available to him ...."71 F. Supp. at 228.

3s The court approved the use of evidence of trial inconvenience in establishing the impropriety of the plaintiff's motive. 208 Miss. at 376,44 So.2d at 471 .

36 Although acknowledging the doctrinal requirement of improper purpose, the court in Northern Pac. Ry. v. Richey \& Gilbert Co., 132 Wash. 526, 232 Pac. 355 (1925), issued an 
An alternative method for softening the improper motive requirement lies in the ambiguity of many of the formulas used to express the requirement. If it is said that an injunction will issue to avoid "fraud, gross wrong, or oppression," 37 the latter two criteria may refer either to the plaintiff's conduct in choosing the forum or to the consequences of that choice on the defendant's convenience. The plaintiff's motive may be to oppress or he may unwittingly create circumstances in fact oppressive. With formulas of such ambiguity, an enjoining court is free to require distinct proof of improper motive or to employ an analysis the same as that used on a motion to dismiss for forum non conveniens. ${ }^{38}$

\section{II}

In addition to these variations in the basic rules for relief, differences between the two remedies arise in the application of the factors of trial convenience. According to the doctrine of forum non conveniens, the formal basis for the decision is the relative suitability of the competing forums. The exclusive ground for relief is the finding by the court of a degree of relative inconvenience deemed sufficient to warrant transfer. With the alternative remedy, transfer by injunction, the formal basis for relief is the impropriety of the plaintiff's motive in selecting the original forum. An injunction will issue on proof of trial inconvenience sufficient to give rise to an inference that the choice of forum was improperly motivated; yet the injunction may also issue without proof of trial inconvenience in the ordinary sense. An improperly motivated plaintiff may inititate a suit and yet not create conditions that would support a motion for dismissal on the ground of forum non conveniens.

injunction on considerations solely of inconvenience and expense. Showing regard for the doctrinal requirement, the Court concluded that "the facts in this case show there is some appearance of vexation. ..."132 Wash. at 533, 232 Pac. at 358.

In Standard Roller Bearing Co. v. Crucible Steel Co., 71 N.J. Eq. 61, 63 Atl. 546 (1906), the court enjoined the prosecutions of plaintiff's claim on distinct attachments in three Midwestern states. Refuting the plaintiff's protestations of good faith, the court regarded the factual circumstances as conclusion of the plaintiff's motivation: "That the use of attachments, having [the] ... obvious result [of harrassing and oppressing the plaintiff] was not intended to produce the result, is not within the range of belief." 71 N.J. Eq. at $65,63 \mathrm{Atl}$. at 547-48:

For a criticism of the dangers inhering in facile inferences at to the plaintiff's motive, see Missouri Pac. Ry. v. Harden, 158 La. 889, 105 So. 2 (1925).

37 This particular phrase was employed in Illinois Life Ins. Co. v. Prentiss, 277 Ill. 383, 387, 115 N.E. 554, 556 (1917). Analogous expression of the criterion for relief may be found, for example, in Payne v. Knapp, 197 Iowa 737, 743, 198 N.W. 62, 64 (1924) ("fraud, undue hardship, or oppression"); Bavuso v. Angwin, 166 Kan. 469, 201 P.2d 1057 (1940); Keisker v. Bush, $210 \mathrm{Ky} .718,722,276$ S.W. 815, 816 (1925) ("unfair or unconscionable advantage").

38 The Iowa courts have interpreted "vexatious litigation" to be a concept of consequences, not of purpose. A passage from Wabash Ry. v. Peterson, 187 Iowa 1331, 175 N.W. 523.(1919), quoted in Bankers Life Co. v. Loring, 217 Iowa 534, 542, 250 N.W. 8, 12 (1933), pinpoints this line of interpretation: Without reference to actual intention, there is no escaping from the conclusion that on the facts at bar the suit is an instance of vexatious litigation such as is condemned by the quite general consensus of authority. (Emphasis added). 
If, as in Mason v. Harlow, 39 the defendant were engaged in prosecuting a different claim against the plaintiff in a nearby state, the inconvenience to the defendant in being forced to litigate in two forums would not involve the usual forum non conveniens considerations-expense, distance, availability of witnesses, etc. A dismissal would require an unusual application of the doctrine of forum non conveniens. The defendant could, however, readily obtain injunctive relief on satisfactory proof that the plaintiff's motive was to hinder the defendant in the prosecution of his action in the neighboring state.

\section{III}

Occasionlly, injunctions are issued without regard either for the criteria of trial convenience or the propriety of the plaintiff's motive, but rather to promote interests local to the enjoining forum. Some courts, for example, have sought to prevent the "exportation" of particular classes of claims arising within the state; 40 others have issued injunctions in order to guarantee the application of local law to controversies based on domestic incidents. ${ }^{41}$

Similarly, in applying the doctrine of forum non conveniens, the forum's interest in relieving court congestion often affects its determination of the desirability of transferring an action to another jurisdiction. 42 In all border-

39 84 Kan. 277, 114 Pac. 218 (1911); cf. Standard Roller Bearing Co. v. Crucible Stcel Co., 71 N.J. Eq. 61, 63 Atl. 546 (1906).

40 Nonexportation policies have been pursued in deference to venue statutes locating actions against railroads in specified counties within the state. Pere Marquette Ry. v. Slutz, 268 Mich. 388, 256 N.W. 458 (1934); New York, C. \& St. L. Ry v. Matzinger, 136 Ohio St. 271,25 N.E. $2 d 349$ (1940). Both statutes involved, however, referred to actions intended to be initiated within the state.

In Wabash Ry. v. Peterson, 187 Iowa 1331, 175 N.W. 523 (1919), the court reasoned that the prevention of exportation of domestic claims was part of the state's public policy. Supporting the conclusion was a statute declaring it to be unlawful to solicit claims for prosecution outside of the state.

41 Differing forum law in negligence cases has prompted the forum with the rule more advantageous to the defendant to enjoin the prosecution of the action in a sister forum. Weaver v. Alabama Great So. Ry., 200 Ala. 432, 76 So. 364 (1917); Sanders v. Yates, 215 Ga. 218, 109 S.E.2d 739 (1959). In Culp v. Butler, 69 Ind. App. 668, 122 N.E. 684 (1919), the out-of-state action was enjoined because the statute of limitations had run in the enjoining forum - the state in which the claim had arisen and in which the plaintiff resided. But $c f$. Royal League v. Kavanagh, 233 III. 175, 84 N.E. 178 (1908), in which the injunction was denied in deference to the choice-of-law policy of the sister forum.

42 References to the forum's interest in relieving court congestion are ubiquitous. See, e.g., Cotton v. Louisville \& N.R.R., 14 Ill. 2d 144, 152 N.E.2d 385 (1958); Universal Adjustment Corp. v. Midland Bank, Ltd., 281 Mass. 303, 184 N.E. 152 (1933); St. Louis, S.F. Ry. v. Superior Court, 276 P.2d 773 (Okla. Sup. Ct. 1954).

For a vigorous discussion of the relevance of congestion in the forums to which transference might be directed, see the opinions of the court and of Pratt, C. J., dissenting in Mooney v. Denver 118 Utah 300, 221 P.2d 628 (1950).

Authority is divided upon the manner in which court congestion should influence forum non conveniens policy. The firm position of Anderson v. Delaware, L. \& W. R.R., 18 N.J. Misc. 153, 11 A.2d 607 (Cir. Ct. 1940), is that court congestion is a factor relevant to the desirability of a forum non conveniens policy, but not relevant to deciding the advisability 
line situations, the likelihood of dismissal increases with the desire of the forum to reduce the burden on its docket. To implement a policy of reducing congestion, the court may lower the degree of inconvenience that the defendant must prove, or it may even shift to non-resident plaintiffs the duty of justifying the retention of jurisdiction. 43

The forum's local interests tend to benefit the defendant in a variety of ways. If a forum issues an injunction to secure application of its own law to a claim arising within the state, the defendant is given the opportunity to obtain relief whenever the sister forum refuses to apply the lex loci in deciding the case. Consequently, the local policy of the enjoining forum adds a new basis for relief. In contrast to this relatively specialized application, a forum policy designed to reduce congestion in its courts increases the likelihood of a forum non conveniens dismissal in every case in which the appropriateness of the forum can reasonably be questioned.

Thus, the more advantageous remedy in a particular situation will depend in part on the local policies of the forums from which relief might be obtained. A forum non conveniens motion is advisable if the forum in which the action is pending wishes to assure, as do most metropolitan courts, that the amount of litigation will be minimized. Analogously, a suit for an injunction is likely to be successful if the courts in the state in which the claims have arisen follow a policy of preventing the "exportation" of domestic actions. Although local interests may render relief under one remedy more likely than under the alternative, the more desirable method of obtaining a transfer need not be the only method; failure under one remedy does not preclude recourse to the other.

But a choice between the two remedies is not always available. The doctrine of forum non conveniens cannot be invoked in every situation in which a relocation of the action would be desirable. Many states reject the doctrine entirely; and of those in which it is applied, relief is unlikely if either party is a resident of the forum state. When transfer is blocked for these reasons, the inconvenienced defendant may seek an injunction against the plaintiff's proceeding in his chosen forum. By use of the injunction, a transfer may be obtained from any jurisdiction, but owing to the difficulties of enforcing injunc-

of transference in a particular. case. But $c f$. Ramsey v. Chicago Great W. Ry., 247 Minn. 217, 77 N.W. 2d 176 (1956) (dissenting opinion) in which it was decided that F.E.L.A. claims, as a major burden on the docket, should be dismissed more readily than other actions.

Contrary to the assumptions of jurisdictions favoring forum non conveniens as an instrument of docket control, one court has argued that dismissing claims may actually increase litigation in the jurisdiction by virtue of appeals filed by plaintiffs seeking to reverse the dismissal of these claims. Lansverk v. Studebaker-Packard Corp., 54 Wash. 2d 174, 338 P.2d 747 (1959).

43 Generally the burden of justifying dismissal is on the defendant. Gulf Oil Corp. v. Gilbert, 330 U.S. 501 (1947); Running v. Southwest Freight Lines Inc., 227 Ark. 839, 303 S.W. 2d 578 (1957). 
tions under present practice, the injunction decree is not a fully effective alternative to a forum non conveniens dismissal,44

The difficulties of enforcing injunctions against suit would disappear if the full faith and credit clause were interpreted to require recognition of the injunction in the original forum: the original forum would be constitutionally compelled to dismiss the action; it could neither refuse to enforce nor enjoin the enforcement of the injunction. With the assurance that an injunction decree would be recognized by the original forum, the defendant could effectively transfer a suit from any jurisdiction-including those that do not now apply the doctrine of forum non conveniens. Overcoming another limitation on the transfer of suits by forum non conveniens, a defendant could secure transfer both as a resident and against residents of the forum state. By superseding individual state policies restricting the use of forum non conveniens, the extension of full faith and credit recognition to injunctions against suit would create an effective nation-wide method for relieving defendants from undue trial inconvenience.

The distinguishing characteristic of a system in which injunctions against suit were accorded full faith and credit would be the capacity of an enjoining forum to compel a dismissal in the original jurisdiction. With this power, a forum could more effectively relocate an action in the interest of convenience. Moreover, it could more effectively implement local policies independent of sparing expense and inconvenience to the parties. For example, when assured of recognition, an injunction would be a more useful way to prevent sister forums from making choice-of-law decisions which ignore the relevant connections of the enjoining forum to the action. If a sister forum indiscriminately applies its own law in an action which is between retidents of the enjoining state and which is almost wholly unrelated to the fonm in which it is pend-

44 A significant advantage of an injumction suit is the appeakability of the denial of relief. In forum non conveniens practice, only two jurisdictions-Nuw Jersey and New Yorkpermit direct appeals from a refusal to dismiss. Gore v. United States Steel Corp., 15 N.J. 301, 104 A.2d 670 (1954); Williams v. Seaboard Air Line R.F, 9 App. Div. 2d 268, 193 N.Y.S. 2d 588 (1959); Rodriguez v. A. H. Bull Steamship Co., 268 App. Div. 207, 143 N.Y.S. 2d 618 (1955).

However, in jurisdictions which do not permit such interlowntory appeals, appeal from a denial to dismiss must be taken after trial, verdict and judgrient. In this situation, little can be said on appeal as to the advisability of a transference fors the purpose of trial convenience. Indicating perhaps that a trial cures all abuses of dirctetion in not dismissing, no recorded case stands for a reversal after a judgment for the perty having initially selected the forum - the plaintiff. Cases affirming a denial to dismiss arowumerous. See, e.g., Cotton v. Louisville \& N.R.R., 14 Ill. 2d 144, 152 N.E.2d 385 (1958); Homer v. Pleasant Creek Mining Corp., 165 Ore. 683, 107 P.2d 989 (1940).

The Oklahoma Supreme Court has permitted the use of the extraordinary writs of mandamus and prohibition to review denials of motions to dismiss. St. Louis, S.F. Ry. v. Superior Court, 290 P.2d 118 (Okla. Sup. Ct. 1955) (mandamus held available against an arbitrary abuse of discretion); St. Louis, S.F. Ry. v. Superior Court, 276 P.2d 773 (Okla Sup. Ct. 1954) (writ of prohibition issued where the trial judge believed he had no authority to enter a dismissal). Over a strong dissent by Justice Schaefer, the Illinois Supreme Court refused to sanction the use of extraordinary writs to correct an exercise of discretion, however abusive. Cotton v. Louisville \& N.R.R., 14 Ill. 2d 144, 152 N.E.2d 385 (1957). 
ing, the enjoining forum could override the choice-of-law decision of the sister forum by using.the injunction to acquire jurisdiction over the action. It is doubtful, however, whether an enjoining forum could systematically use injunctions to prevent litigation in sister forums of all action in which it claimed a state interest. By analogy to the denial of full faith and credit recognition to state statutes proscribing the exportation of domestic claims, the nondiscretionary issuance of injunctions to achieve a similar purpose would fail to create an obligation in sister forums to recognize the decrees.

As a consequence of full faith and credit recognition of injunctions and the equality of power between the enjoining forum and the original forum to relocate the action, an accommodation of the two remedies would be necessary to avoid inconsistent decisions on the advisability of granting relief. The need for acommodation would be limited to the circumstance of a denial of relief under one remedy prior to the granting of a transfer under the alternative remedy; for relief under either remedy would prompt a relocation of the action, rendering moot the possibility of recourse to the alternative method of transfer.

To avoid the circumstance of relief in one forum conflicting directly with a prior decision of another forum not to permit a transfer, the participating forums might inyoke the principal of collateral estoppel. After the defendant unsuccessfully sought relief by one remedy, alternative forums would consider him estopped from relitigating issues already adjudicated. Issues decided on a forum non conveniens denial could not be raised anew in an injunction suit, and adjudications of issues by a denial of injunctive relief would similarly be binding on the original forum. In the use of each remedy, however, the issue adjudicated may be defined with varying decrees of specificity. On a motion for a forum non conveniens dismissal, the issue may be thought to be whether the action should be transferred, whether it should be transferred on the ground of inconvenience, or whether it should be transferred on the basis of the type of inconvenience present in the particular case. Similarly, the issue in a suit for an injunction may be defined broadly or narrowly. Thus, even if a forum is amenable to extending collateral estoppel protection to a plaintiff who has withstood one attempt by his adversary to transfer the action, an appropriate characterization of the issue decided in the sister forum would leave the forum free to exercise its discretion to grant relief. To the extent that the issues were defined narrowly, relief could be permitted after an unsuccessful attempt to transfer by the alternative means. In particular, to the extent that forums were willing to issue injunctions over a previous denial to dismiss by the original forum, the original forum would be deprived of the capacity to effectuate a policy of retaining jurisdiction over specified claims. Since the required recognition of injunctions would not affect the prerogative of an enjoining forum to define its own policy toward forum non conveniens decisions of the original forum, the extent to which injunctions would issue over 
forum non conveniens denials would depend solely on the policy of the enjoining forum.

If a nation-wide system of transfer is to be based on the command of full faith and credit, the medium of locating actions in the most convenient forums will be the control of enjoining forums over the jurisdiction of original forums. Yet this medium is the primary disadvantage of the proposed change. Forums subject to the duty to recognize sister forum injunctions would substantially be deprived of jurisdictional control. A forum non conveniens denial would not guarantee a trial in the original forum; for after the denial to dismiss, sister forums might compel a relocation of the action either in the interest of convenience or for the sake of forcing a change of law.

As an alternative to extending the present rules of full faith and credit, the general adoption of the doctrine of forum non conveniens would create an effective method of transferring actions to or from any jurisdiction. Like injunctions assured of recognition, the comparatively simple remedy of the discretionary dismissal could effectively relieve any defendant situated in an inappropriate forum. Yet unlike a system of transfer based on the mandatory recognition of injunctions, a system groundęd in voluntary forum participation would not entail a qualification of forum autonomy. Dismissals would be discretionary, not compelled by the Constitution; and the relationship between the forums participating in the transfer would be a relationship of cooperation, not control.

If the states should uniformly adopt the doctrine of forum non conveniens, ${ }^{45}$ the rationale for full faith and credit recognition of injunctions

45 States have rejected the doctrine of forum non conveniens on the bases of (1) state statutory policy, (2) federal constitutional law and (3) the undesirability of the policy. In Alabama, Missouri, and Texas, transfers of actions to other states have been denied on interpretations of local statutes permitting the litigation of claims based on incidents occurring outside the state. Ex parte State ex rel. Southern Ry., 254 Ala. 10, 47 So.2d 249 (1950); State ex rel. Southern Ry. v. Mayfield, 362 Mo. 101, 240 S.W.2d 106 (1951); State ex rel. Pacific Mut. Life Ins. Co. v. Grimm, 239 Mo. 155, 143 S.W. 483 (1911); Allen v. Bass, 47 S.W.2d 426 (Tex. Ct. Civ. App. 1932). In Mattone v. Argentina, 123 Ohio St. 393, 175 N.E. 603 (1931), the Ohio court regarded the doctrine of forum non conveniens as incompatible with the "statutory and constitutional provisions of the state." Id. at 398,175 N.E. at 605. However, the statute adverted to in the decision, OHIO GENERAL CODE \$ 11276, defines the extent of permissible, not mandatory, jurisdiction.

In a second class of cases, the privileges and immunities clause, U.S. CoNST. art. IV, $\S 2$, has been the basis of refusals to vest trial courts with the power to grant discretionary dismissals. Access to the courts of the state has been thought to be a privilege of state citizenship: by interpretation of the constitutional command, the privilege has been extended to noncitizens as well as citizens. Bourestrom v. Bourestrom, 231 Wis. 666, 285 N.W. 426 (1939); Herrmann v. Franklin Ice Cream Co., 114 Nebr. 468, 208 N.W. 141 (1926). The Supreme Court in Douglas v. New York, N.H. \& H. R.R., 279 U.S. 377 (1927), held that a forum non conveniens policy based on residence does not contravene the privileges and immunities clause. See note 20 supra.

Recently, Washington has rejected the doctrine of forum non conveniens solely on the ground that a transfer remedy appeared to be neither desirable nor necessary. Lansverk v. Studebaker-Packard Corp., 54 Wash.2d 124, 338 P.2d 747 (1959). 
would be substantially undercut. If, however, the continued application of rigid residence limitations prevented a significant number of inconvenienced defendants from obtaining discretionary dismissals, a nonrestricted system of transfer based on mandatory recognition of injunctions would remain an attractive alternative. In large part the desirability of extending full faith and credit recognition to injunctions depends on state initiative in expanding the use of forum non conveniens. If the states are recalcitrant, the application of the full faith and credit clause may be necessary to assure relief for every defendant unduly inconvenienced by his adversary's choice of forum. 